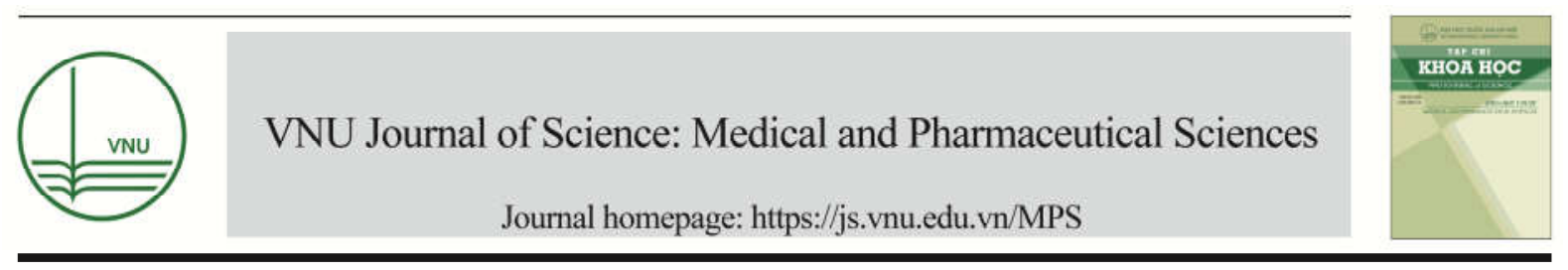

\title{
The Association between the Gly972Arg Polymorphism in IRS1 Gene and the Risk of Prediabetes among Vietnamese Women
}

\author{
Nguyen Thi Trung Thu ${ }^{1}$, Tran Quang Binh, ${ }^{2, *}$ \\ ${ }^{1}$ Falcuty of Biology, Hanoi National University of Education, 136 Xuan Thuy, Cau Giay, Hanoi, Vietnam \\ ${ }^{2}$ Department of Scientific Management, National Institute of Nutrition, \\ 48B Tang Bat Ho, Pham Đinh Ho, Hai Ba Trung, Hanoi, Vietnam
}

Received 26 October 2018

Revised 07 November 2018; Accepted 25 December 2018

\begin{abstract}
Insulin receptor substrate 1 (IRS1), a ligand of the insulin receptor tyrosine kinase, participates in the insulin receptor signal transduction pathway. Dysregulations in IRS1 expression and function increase incidence of insulin-resistant states such as prediabetes and type 2 diabetes. The study was aimed at investigating the association of the Gly972Arg (rs1801278) polymorphism in IRS1 gene with prediabetes in Northern Vietnamese women. The case-control study consisted of 1,617 women (250 prediabetic cases and 1,367 normoglycemic controls). The IRS1 Gly972Arg polymorphism was genotyped in these subjects using polymerase chain reaction-restriction fragment length polymorphism. The frequency of the " $\mathrm{A}$ " allele of the Gly972Arg (G>A) polymorphism was similar between the normal glucose and prediabetic subjects $(2.7 \%$ and $2.6 \%$, respectively). There was no significant difference in the genotypic frequency between the control and prediabetic cases $(P=0.673)$. The IRSI Gly972Arg polymorphism was not associated with the risk of prediabetes in Vietnamese women both before and after being adjusted for socio-economic, lifestyle and clinical factors $(P>0.05)$.
\end{abstract}

Keywords: Gly972Arg, polymorphism, IRS1 gene, prediabetes, Vietnamese women.

\section{Introduction}

Prediabetes, defined as blood glucose levels above normal but below diabetes thresholds, is a high-risk state for developing diabetes [1]. The prevalence of prediabetes is often two to three times higher than the prevalence of

\footnotetext{
${ }^{*}$ Corresponding author. Tel.: 84-904470844.

Email: tranquangbinh@dinhduong.org.vn

https:// doi.org/10.25073/2588-1132/vnumps.4129
}

diabetes and varies among populations and ethnic groups. According to the report of Centers for Disease Control and Prevention prevalence of diabetes and prediabetes in population aged 18 years or older in 2017 was $9.4 \%$ and $33.9 \%$, respectively, in the United States [2]. Prevalences of diabetes and prediabetes in Northern Norway were $9.4 \%$ and $35.4 \%$, respectively [3]. The age and sexadjusted prevalence rates of diabetes, and 
prediabetes in Vietnamese adults aged $40-64$ years was $3.7 \%$, and $14.6 \%$, respectively [4].

It is worrying that prediabetes often shows no clinical symptoms. Current estimates indicate that most individuals (up to $70 \%$ ) with prediabetic states, who are not detected early and intervened timely, eventually will develop type 2 diabetes in their lifetime [5]. Moreover, people with prediabetes are at greater risk for heart attack, kidney disease, nerve damage, fatty liver disease, vision problems, cancer and high blood pressure, compared to people without the disorder [6].

It is necessary to screen and detect prediabetic status early based on risk factors such as genetic variants and environmental factors that affect both insulin secretion and insulin resistance. Thereby, there are timely interventions to reduce the incidence of prediabetes and to limit progression to diabetes and other serious diseases in the future.

Insulin receptor substrate 1 (IRSI), a ligand of the insulin receptor tyrosine kinase, participates in the insulin receptor signal transduction pathway. So that dysregulation in IRSI expression and function has been reported in insulin resistance such as prediabetes and type 2 diabetes [7]. Many polymorphisms described in IRS1 gene included Pro512Ala, Asn1137Arg, Arg158Pro, and Gly972Arg. Among those, the Gly972Arg polymorphism (rs1801278) is shown to be associated with the risk of insulin resistance and type 2 diabetes $[8,9]$. However, there have been almost no studies on the association between the Gly972Arg polymorphism in IRSI gene and the risk of prediabetes. Therefore, this study was conducted to determine the association between the Gly972Arg polymorphism of IRS1 gene and the risk of prediabetes among Northern Vietnamese women.

\section{Subjects and methods}

\subsection{Subjects}

The case-control study consisted of 1617 women (250 prediabetic cases and 1367 normoglycemic controls). They were recruited from a cross-sectional study with people aged 40 - 64 years in the general population of the Red River Delta, Vietnam. The details of the survey to collect data were reported previously [4]. The study was approved by The Ethics Committee of the National Institute of Hygiene and Epidemiology, in Vietnam. Before entering the study, all participants were provided written informed consent.

\subsection{Data collection}

Charateristics of subjects included anthropometric parametric (weight, height, waist circumference, hip circumference, body fat percentage, systolic blood pressure, and diastolic blood pressure). Body mass index is caculated as weight per square of height $\left(\mathrm{kg} / \mathrm{m}^{2}\right)$. Waist-hip ratio was calculated as waist circumference divided by hip circumference. Body fat percentage was measured by bioelectrical impedance method by using OMRON scale (HBF-351, Kyoto, Japan).

Participants had not eat or drink anything but water for 8 hours - 16 hours prior to the clinic visit. Firstly, blood samples were collected and centrifuged immediately in the morning to test fasting plasma glucose (FPG) and lipid profile (total cholesterol, triglycerides, high-density lipoprotein cholesterol, and lowdensity lipoprotein cholesterol). Then participants had to drink $75 \mathrm{~g}$ glucose with $200 \mathrm{ml}$ water, after 2 hours, intravenous blood sample was collected to test oral glucose tolerance.

Glucose and lipid profile were analyzed using a semi-autoanalyzer (Screen Master Lab; Hospitex Diagnostics LIHD112, Italy) with commercial kit (Chema. Diagnostica, Italy). Plasma glucose was measured by glucose oxidase method (GOD-PAP). Lipid profile were measured by enzymatic methods.

Dyslipidemia is defined as high-density lipoprotein $\leq 50 \mathrm{mg} / \mathrm{dL}$ for female, and total cholesterol, low-density lipoprotein and triglyceride levels $\geq 200, \geq 130$ and $\geq 130$ $\mathrm{mg} / \mathrm{dL}$, respectively [10]. 
All participants had to completed structured questionnaires to collect data included current age, residence, gender, ethnicity, education, occupation, marital status, income level, alcohol consumption, smoking history, time spent for night's sleep, siesta, watching television, family history of diabetes, medical and reproductive history.

\subsection{Diagnosis of prediabetes and normal glucose}

The glycaemic status of subjects was determined using FPG and glucose after 2 hours using oral glucose tolerance test (OGTT) [11].

Participants were classified as having prediabetes if FPG was between 5.6 and 6.9 $\mathrm{mmol} / \mathrm{L}$, and/or 2 hour plasma glucose was from 7.8 to $11.0 \mathrm{mmol} / \mathrm{L}$. Normal glucose tolerance was characterized by FPG $<5.6 \mathrm{mmol} / \mathrm{L}$ nd 2 hour plasma glucose $<7.8 \mathrm{mmol} / \mathrm{L}$ [12].

\subsection{Genotyping}

Genotyping peripheral blood samples were obtained from each participant and genomic DNA was extracted from peripheral blood leukocytes, using Wizard ${ }^{\circledR}$ Genomic DNA Purification Kit (Promega Corporation, USA) accoding to manufacturer. The purity and concentration of DNA were measured by
NanoDrop. All samples were genotyped using polymerase chain reaction - restriction fragment length polymorphism (PCR-RFLP) analysis. The protocol of RFLP methods were described previously [13].

\subsection{Statistical analysis}

Subjects' characteristics are expressed by mean \pm standard deviations (with normal distribution), or median and interquartile range (without normal distribution) for quantitative variables. The frequencies of alleles and genotypes were compared, and tested for Hardy-Weinberg equilibrium (HWE) by Fisher's exact test. The influence of genetic factors was assessed by five genetic models (dominant, co-dominant, over-dominant, recessive, and additive model) using single logistic regression and multilogistic regression adjusted by age, sex, anthropometric factors, socio-economic and environmental factors [14]. Statistical analyses were performed on SPSS 16.0 software. Statistical significance was determined with a $P$ value $<0.05$ on both sides.

\section{Results and discussion}

\subsection{Characteristics of the study subjects}

Table 1. Characteristics of the study subjects in prediabetic cases and controls

\begin{tabular}{|c|c|c|c|}
\hline Characteristics & Controls $(\mathrm{N}=1367)$ & Prediabetic cases $(\mathrm{N}=250)$ & $P$-value \\
\hline Age (years) ${ }^{\mathrm{a}}$ & $50(45-55.07)$ & $53(47-58)$ & $<0.0001$ \\
\hline Height $(\mathrm{cm})$ & $152.32 \pm 4.94$ & $151.49 \pm 5.07$ & 0.013 \\
\hline Weight $(\mathrm{kg})$ & $49.52 \pm 6.93$ & $49.05 \pm 6.69$ & 0.308 \\
\hline Body mass index $\left(\mathrm{kg} / \mathrm{m}^{2}\right)$ & $21.32 \pm 2.64$ & $21.32 \pm 2.52$ & 0.998 \\
\hline Body fat percentage (\%) & $29.89 \pm 4.61$ & $30.31 \pm 4.43$ & 0.176 \\
\hline Waist circumference $(\mathrm{cm})^{\mathrm{a}}$ & $73(67.5-78)$ & $73(68-78)$ & 0.266 \\
\hline Hip circumference $(\mathrm{cm})^{\mathrm{a}}$ & $87.5(88-91)$ & $87(83-91)$ & 0.036 \\
\hline Waist-hip ratio & $0.83 \pm 0.06$ & $0.85 \pm 0.06$ & 0.005 \\
\hline Systolic blood pressure $(\mathrm{mmHg})^{\mathrm{a}}$ & $110(100-120)$ & $120(110-135)$ & $<0.0001$ \\
\hline Diastolic blood pressure $(\mathrm{mmHg})^{\mathrm{a}}$ & $70(60-80)$ & $80(70-80)$ & $<0.0001$ \\
\hline Total cholesterol $(\mathrm{mmol} / \mathrm{L})^{\mathrm{a}}$ & $4.22(3.9-4.88)$ & $4.5(4.09-5.0)$ & $<0.0001$ \\
\hline Low-density lipoprotein $(\mathrm{mmol} / \mathrm{L})^{\mathrm{a}}$ & $2.79(2.31-3.32)$ & $3.1(2.66-3.7)$ & $<0.0001$ \\
\hline High-density lipoprotein $(\mathrm{mmol} / \mathrm{L})^{\mathrm{a}}$ & $1.25(0.99-1.6)$ & $1.22(0.97-1.57)$ & 0.141 \\
\hline Triglyceride $(\mathrm{mmol} / \mathrm{L})^{\mathrm{a}}$ & $1.3(1.0-2.0)$ & $1.76(1.05-2.35)$ & $<0.0001$ \\
\hline
\end{tabular}

Data are mean $\pm S D$ values. ${ }^{a}$ Data are median (interquartile range).

$P$-value by Student T test or Mann-Whitney U test. 
The characteristics of subjects in controls and prediabetic cases are shown in Table 1 . There were significant differences between control and prediabetic group in age, height, hip circumference, waist-hip ratio, systolic blood pressure, diastolic blood pressure, total cholesterol, low-density lipoprotein, and triglyceride. No significant difference in weight, waist circumference, body mass index, body fat percentage and high-density lipoprotein was observed.

\subsection{Genotype and allele frequencies}

Table 2 shows the frequencies of $\mathrm{A}$ and $\mathrm{G}$ alleles, and genotypes of the Gly972Arg polymorphism in controls and prediabetic cases. The frequency of minor allele (A) was $2.7 \%$ in total cohort. Distribution of genotype and allele frequencies in normal glucose group is imbalanced $(P=0.002)$. No significant difference in genotype and allele frequencies was observed between normal glucose and prediabetic groups $(P>0.05)$.

Table 2. Genotype and allele frequencies of the Gly972Arg polymorphism

\begin{tabular}{llllll}
\hline Frequencies & & $\begin{array}{l}\text { Total } \\
(n=1617)\end{array}$ & $\begin{array}{l}\text { Controls } \\
(n=1367)\end{array}$ & $\begin{array}{l}\text { Prediabetic cases } \\
(n=250)\end{array}$ & $P$-value \\
\hline Genotype & AA & $4(0.2 \%)$ & $4(0.3 \%)$ & $0(0 \%)$ & 0.673 \\
& AG & $79(4.9 \%)$ & $66(4.8 \%)$ & $13(5.2 \%)$ & \\
\hline Allele & GG & $1534(94.9 \%)$ & $1297(94.9 \%)$ & $237(94.8 \%)$ & 0.890 \\
& G & $87(2.7)$ & $74(2.7)$ & $13(2.6)$ & \\
\hline
\end{tabular}

The data in the table are presentende by $n(\%)$, HWE: Hardy - Weinberg equation $P$-values were from $\chi^{2}$ test or Fisher exact.

Table 3. Association between the Gly972Arg polymorphism and the risk of prediabetes

\begin{tabular}{llllll}
\hline Models & Genotype & OR $(95 \% \mathrm{CI})$ & $P$-value & OR $^{*}(95 \% \mathrm{CI})$ & $P^{*}$-value \\
\hline \multirow{2}{*}{ Co-dominant } & GG & 1 & & 1 & \\
& AG & $1.08(0.59-1.99)$ & 0.798 & $0.97(0.48-1.99)$ & 0.941 \\
& AA & - & - & - & - \\
\hline \multirow{2}{*}{ Dominant } & GG & 1 & & 1 & \\
& AG-AA & $1.02(0.56-1.87)$ & 0.879 & $0.92(0.45-1.87)$ & 0.809 \\
\hline \multirow{2}{*}{ Recessive } & GG-AG & 1 & - & 1 & - \\
\hline \multirow{2}{*}{ Over-dominant } & GA & - & - & 1 & 0.947 \\
\hline Additive & AG & $1.09(0.59-2.0)$ & 0.791 & $0.98(0.48-2.0)$ & 0.697 \\
\hline
\end{tabular}

$P$-value was received from unvariate logistic regression, $P_{-}^{*}$ value was received from multitvariate logistic regression adjusted for age, body fat percentage, maximum blood pressure, minimum blood pressure, $H D L-C, L D L-C$, triglyceride, cholesterol, marital status, education, income level, family history of diabetes, time spent for night's sleep, siesta, watching television, alcohol consumption, and smoking history.

3.3. The association between the Gly972Arg polymorphism and the risk of prediabetes in Hanam women

The influence of genetic factors was assessed by five genetic models (dominant, co- dominant, over-dominant, recessive, and additive model) using univariate logistic regression and multivariate logistic regression adjusted for socio-economic, lifestyles and clinical factors. 
No significant association between the Gly972Arg polymorphism in IRS1 gene and the risk of prediabetes in five genetic models before and after adjusted for age, body fat percentage, maximum blood pressure, minimum blood pressure, HDL-C, LDL-C, triglyceride, cholesterol, marital status, education, income level, family history of diabetes, time spent for night's sleep, siesta, watching television, alcohol consumption, and smoking history $(P>0.05)$.

IRSI gene plays a critical role in insulin signaling. So the dysregulation of IRSI gene has an important place in the development of insulin resistance. The tyrosine phosphorylation of IRSI serves as docking molecules for downstream effectors such as phosphatidylinositol 3-kinase and phosphotyrosine phosphatase-2 [15]. However, our study has reached no association between the Gly972Arg polymorphism and the risk of prediabetes in Hanam women.

The frequency of allele $\mathrm{A}$ in normal group $(2.7 \%)$ was quite similar to the frequency of allele A in Mexico population (2.6\%) [8], Han Chinese in Beijing (2.3\%), higher than those in Africans in South West Africa (1\%), and lower than those in the Japanese population $(8.1 \%)$, Indian $(9 \%)$, Utah residents with Northern and Western European ancestry from the CEPH collection $(5.8 \%)$ [16].

In recent years, a great number of risk gene/allele in type 2 diabetes pathogenesis were found with the contribution of Genome wide association (GWA) studies. But the molecular mechanisms are mostly unknown. The Gly972Arg polymorphism was found to be associated with type 2 diabetes in different populations such as Mexico [8], Malaysia [9], meta-analysis [17]. According to MarntisnezGómez, heterozygosity for the Gly972Arg variant of the IRSI gene showed the strongest association for T2D adjusting by ancestry, age, gender, and BMI in both Guerrero and Mexico city samples $(\mathrm{OR}=2.43,95 \% \mathrm{CI}=1.12-5.26$ and $2.64,95 \% \mathrm{CI}=1.37-5.10$, respectively) in Mexico population [18]. IRS is an important ligand in the insulin response of human cells and IRS-1, for example, is an IRS protein that contains a phosphotyrosine binding-domain. So IRS-1 protein is know as a major substrate for the insulin receptor and is present in tissues that are involved in glucose production, and insulin secretion [19]. In knockout models, this polymorphism was reported to inhibit insulin signaling that is dependent on phosphatidylinositol 3-kinase in tissues which are sensitive to insulin, expecially muscle and pancreatic $\beta$-cells. This causes multiple defects, including the translocation of the glucose transporter [20]. Morover, many studies showed that insulin secretion is lower in pancreatic $\beta$-cells that express the Gly972Arg polymorphism compared with carriers with the wild-type IRSI variant. This suggested that this polymorphism decreases the ability of $\beta$-cells to compensate insulin resistance [19].

On the other hand, we did not find any association in our population similar to some other populations such as United State and Poland population [21], United Kingdom population [22], South Indian population [23], Turkish population [15], Japan population [24]. While affecting the attributes of glucose homeostasis such as fasting glucose and insulin action, this variant still does not appear to influence prediabetes. Firstly, small sample sizes were affected the detection of the association between the Gly972Arg polymorphism and the risk of prediabetes. Secondly, the association signal reported by others may not be due to Gly972Arg, but another nearby genetic variant. So that, to eliminate this possibility, a thorough understanding of the haplotype structure of the IRS1 region and a systematic assessment of its common genetic variation in very large diabetes patient samples is required [23]. Thirdly, the Gly972 residue is located between two potential sites of tyrosine phosphorylation involved in the binding of phosphoinositide 3kinase. Replacement of the small uncharged amino acid, glycine, by the large positively 
charged arginine is likely to result in an impairment in the binding of the phosphoinositide 3-kinase with IRSI [25].

\section{Conclusions}

Our results suggest that the Gly972Arg polymorphism in IRSI gene may have no contribution on genetic architecture of prediabetes in the Vietnamese women. Maybe larger sample sizes will be required to detect the association between IRSI gene and the risk of prediabetes in Vietnamese population.

\section{Acknowledgments}

The study was supported by Vietnam's National Foundation for Science and Technology Development (NAFOSTED), for "A 5-year prospective study on type 2 diabetes and metabolic syndrome in Vietnamese: role of genetic and lifestyle-related factors", grant number 106-YS.01-2015.10 from the Ministry of Science and Technology, Vietnam.

\section{References}

[1] A.G. Tabák, C. Herder, W. Rathmann, E.J. Brunner, et al., Prediabetes: a high-risk state for diabetes development, The Lancet 379 (2012) 2279.

[2] The Centers for Disease Control and Prevention, National Diabetes Statistics Report, 2017 Estimates of Diabetes and Its Burden in the United States, 2017 accessed, from https://www.cdc.gov/diabetes/data/statistics/statistic s-report.html.

[3] A. Naseribafrouei, B.-M. Eliassen, M. Melhus, J. Svartberg, et al., Prevalence of prediabetes and type 2 diabetes mellitus among Sami and nonSami men and women in Northern Norway - The SAMINOR 2 Clinical Survey, International Journal of Circumpolar Health 77 (2018) 1463786 .
[4] T.Q. Binh, P.T. Phuong, B.T. Nhung, D.D. Thoang, et al., Prevalence and correlates of hyperglycemia in a rural population, Vietnam: implications from a cross-sectional study, BMC public health 12 (2012) 939.

[5] D.M. Nathan, M.B. Davidson, R.A. Defronzo, R.J. Heine, et al., Impaired fasting glucose and impaired glucose tolerance implications for care, Diabetes Care 30 (2007) 753.

[6] M. Buysschaert, J.L. Medina, M. Bergman, A. Shah, et al., Prediabetes and associated disorders, Endocrine 48 (2015) 371.

[7] A.C. Thirone, C. Huang, and A. Klip, Tissuespecific roles of IRS proteins in insulin signaling and glucose transport, Trends in Endocrinology \& Metabolism 17 (2006) 72-78.

[8] A.I. Burguete-Garcia, M. Cruz-Lopez, V. MadridMarina, R. Lopez-Ridaura, et al., Association of Gly972Arg polymorphism of IRS1 gene with type 2 diabetes mellitus in lean participants of a national health survey in Mexico: a candidate gene study, Metabolism 59 (2010) 38.

[9] H.Z. Huri, M. Makmor-Bakry, R. Hashim, N. Mustafa, et al., Optimisation of glycaemic control during episodes of severe/acute hyperglycaemia in patients with type 2 diabetes mellitus, International journal of clinical pharmacy 34 (2012) 863.

[10] S. Grundy, D. Becker, L. Clark, R. Cooper, et al., Detection, evaluation, and treatment of high blood cholesterol in adults (Adult Treatment Panel III), Circulation-Hagertown, 2002.

[11] American Diabetes Association, 2. Classification and diagnosis of diabetes, Diabetes Care 38 (2015) S8.

[12] American Diabetes Association, Diagnosis and classification of diabetes mellitus, Diabetes Care 33 (2010) S62.

[13] Pham Thu Trang, Nguyen Thi Trung Thu, Pham Tran Phuong, Trang Quang Binh, Le Ngoc Hoan, Identifying Gly972ARG polymorphysm in IRS1 gene in A Vietnamese population by using restriction fragment length polymorphysm method, Proceedings of the 2nd National Scientific Conference on Biological Research and Teaching in Vietnam, Đa Nang (2016) 1279.

[14] X. Solé, E. Guinó, J. Valls, R. Iniesta, et al., SNPStats: a web tool for the analysis of association studies, Bioinformatics 22 (2006) 1928-1929.

[15] H. Arikoglu, M.A. Hepdogru, D.E. Kaya, A. Asik, et al., IRS1 gene polymorphisms Gly972Arg and Ala513Pro are not associated with insulin resistance and type 2 diabetes risk in non-obese Turkish population, Meta gene 2 (2014) 579. 
[16] Hapmap project, accessed 08/06/2018, from https://www.ncbi.nlm.nih.gov/projects/SNP/snp_ref .cgi?rs=rs1801278.

[17] C. Zhang, W. Bao, Y. Rong, H. Yang, et al., Genetic variants and the risk of gestational diabetes mellitus: a systematic review, Human reproduction update 19 (2013) 376.

[18] L.E. Martínez-Gómez, M. Cruz, G.A. Martínez-Nava, V. Madrid-Marina, et al., A replication study of the IRS1, CAPN10, $T C F 7 L 2$, and $P P A R G$ gene polymorphisms associated with type 2 diabetes in two different populations of Mexico, Annals of Human Genetics 75 (2011) 612.

[19] P. Marchetti, R. Lupi, M. Federici, L. Marselli, et al., Insulin secretory function is impaired in isolated human islets carrying the Gly972 $\rightarrow$ Arg IRS-1 polymorphism, Diabetes 51 (2002) 1419.

[20] A.J. McGettrick, E.P. Feener, and C.R. Kahn, Human insulin receptor substrate-1 (IRS-1) polymorphism G972R causes IRS-1 to associate with the insulin receptor and inhibit receptor autophosphorylation, Journal of Biological Chemistry $280(2005) 6441$.
[21] J.C. Florez, M. Sjögren, N. Burtt, M. OrhoMelander, et al., Association testing in 9,000 people fails to confirm the association of the insulin receptor substrate-1 G972R polymorphism with type 2 diabetes, Diabetes 53 (2004) 3313.

[22] E. Zeggini, J. Parkinson, S. Halford, K.R. Owen, et al., Association studies of insulin receptor substrate 1 gene (IRS1) variants in type 2 diabetes samples enriched for family history and early age of onset, Diabetes 53 (2004) 3319.

[23] D. Bodhini, V. Radha, and V. Mohan, Association study of IRS1 gene polymorphisms with type 2 diabetes in south Indians, Diabetes technology \& therapeutics 13 (2011) 767.

[24] H. Mori, M. Hashiramoto, M. Kishimoto, and M. Kasuga, Amino acid polymorphisms of the insulin receptor substrate-1 in Japanese noninsulin-dependent diabetes mellitus, The Journal of Clinical Endocrinology \& Metabolism 80 (1995) 2822.

[25] G. Sesti, Insulin receptor substrate polymorphisms and type 2 diabetes mellitus, Pharmacogenomics 1 (2000) 343.

\title{
Mối liên quan của đa hình Gly972Arg trên gen IRS1 và nguy cơ mắc tiền đái tháo đường ở phụ nữ Việt $\mathrm{Nam}$
}

\author{
Nguyễn Thị Trung Thu ${ }^{1}$, Trần Quang Bình ${ }^{2}$ \\ ${ }^{1}$ Khoa Sinh học, Trường Đại học Su phạm Hà Nội, 136 Xuân Thủy, Cầu Giáy, Hà Nội, Việt Nam \\ ${ }^{2}$ Phòng Quản lí khoa học, Viện Dinh duõng Quốc gia, \\ 48B Tăng Bạt Hổ, Phạm Đình Hổ, Hai Bà Trung, Hà Nội, Việt Nam
}

Tóm tắt: Insulin receptor substrate 1 (IRS1) là một phối tử của thụ thể insulin tyrosine kinase và tham gia vào con đường truyền tín hiệu thụ thể insulin. Sự rối loạn điều hòa trong biểu hiện và chức năng của IRSI làm tăng tî̉ lệ kháng insulin như bệnh tiền đái đường và đái tháo đường týp 2 . Nghiên cứu này nhằm mục đích điều tra mối liên quan của đa hình Gly972Arg (rs1801278) trên gen IRS1 với tiền đái tháo đường ở phụ nữ tại miền Bắc Việt Nam. Nghiên cứu bệnh chứng bao gồm 1617 phụ nữ (250 người mắc tiền đái tháo đường và 1367 người có đường huyết bình thường). Đa hình Gly972Arg trên gen IRS1 được định kiểu gen bằng cách sử dụng phương pháp đa hình chiều dài đoạn cắt giới hạn (PCR-RFLP). Tỉ lệ alen " $A$ " của đa hình Gly972Arg $(\mathrm{G}>\mathrm{A})$ tương tự giữa nhóm glucose huyết bình thường và nhóm tiền đái tháo đường $(2,7 \%$ và $2,6 \%$, tương ứng). Không có sự khác biệt đáng kể về tỉ lệ kiểu gen giữa nhóm glucose huyết bình thường và nhóm tiền đái tháo đường $(P=0,673)$. Chưa nhận thấy mối liên quan của đa hình Gly972Arg trên gen IRSI với tiền đái tháo đường ở phụ nữ miền Bắc, Việt Nam trước và sau khi điều chỉnh theo yếu tố kinh tế xã hội, lối sống và các yếu tố lâm sàng $(P>0,05)$.

Từ khóa: Gly972Arg, đa hình, gen IRS1, tiền đái tháo đường, phụ nữ Việt Nam. 